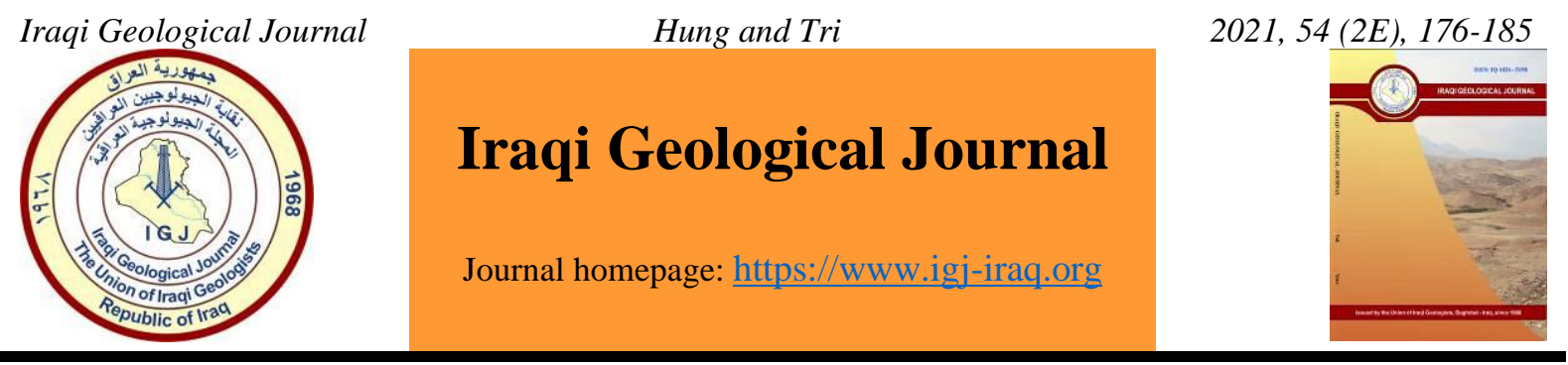

\title{
Hydrothermal and Metasomatic Kaolin Resource Estimation in the Quang Ninh area, Northeastern Vietnam
}

\author{
Khuong The Hung ${ }^{1, *}$ and Le Do Tri ${ }^{2}$ \\ 1 Hanoi University of Mining and Geology, Vietnam \\ 2 Department of Geology and Minerals of Vietnam, Vietnam \\ * Correspondence: khuongthehung@ humg.edu.vn
}

Received: 21 Jue 2021; Accepted: 15 August 2021; Published: 30 November 2021

\begin{abstract}
In northeastern Vietnam, hydrothermal-metasomatic kaolinite-pyrophyllite from the secondary quartzite origin has been found in many places, including Pin Ho, Ban Ngai, Khe Khoai, Pec Sec Leng, Tan Mai ore occurrences, etc. They are exploited together with pyrophyllite, alunite, and high-alumina quartzite as a byproduct. There were 810 chemical and mineral samples in the Quang Ninh area collected to investigate hydrothermal-metasomatic kaolin resources. The ore minerals consist of kaolin-group minerals (kaolinite, dickite), pyrophyllite, quartz with minor sericite, alunite, diaspora, etc. They were identified by X-ray diffraction, and microscope and scanning electron microscope coupled with energy-dispersive X-ray spectroscopy analyses. Chemical analyses of major oxides were carried out on clays and parent rock samples by X-ray fluorescence spectrometry. The similarityanalogy in ore geology and mineral resource estimation based on statistical methods are employed to estimate hydrothermal-metasomatic kaolin resources from the Quang Ninh area in northeastern Vietnam. The mineral resource estimation based on statistical methods shows 2.21 million tons of kaolin obtained by the content of aluminum oxide over $28 \%$ of the Pec Sec Leng mine, accounting for $14.3 \%$ in total. The similarity-analogy in ore geology indicates 158.16 million tons of kaolinite-pyrophyllite ores, of which, 22.0 million tons are kaolin. These methods display that the Quang Ninh area contains mainly pyrophyllite rather than kaolin resources. Our study suggests that the Quang Ninh area can be considered as a potential pyrophyllite resource in northeastern Vietnam for future exploration. Furthermore, the one resource estimation based on similarity-analogy in ore geology method shows an overview of the prospect on kaolinite-pyrophyllite resources in the Quang Ninh area, northeastern Vietnam.
\end{abstract}

Keywords: Kaolinite-pyrophyllite; Resource estimation; Quang Ninh area; Northeastern Vietnam

\section{Introduction}

The hydrothermal-metasomatic type is created on aluminosilicates rock by the action of sulfurous gases or carbon dioxide, gas-water solutions, and thermal waters in general. Commercial deposits of such kaolins are common (Awadh and Yousif, 2015) as shown in the Longmen (Yuan et al., 2014). Because kaolinite belongs to the industrial mineral group which is utilized widely in many disciplines, hydrothermal-metasomatic kaolins play an essential role in producing valuable materials for the ceramic industry. It is used as a feedstock in the manufacture of ceramics, firebricks, cement, and as an additive in the manufacture of paper, paint, fertilizer, rubber, and plastics (Yuan et al., 2014; USGS, 2014).

DOI: $\underline{10.46717 / \text { igj.54.2E.12Ms-2021-11-28 }}$ 
Mineral resource estimation is of practical significance in the mineral investigation (Glacken and Snowden, 2001; Zhang and Huang, 2010; Revuelta, 2018; Kužvart and Böhmer, 1986; Hung et al., 2020). This provides a scientific and practical foundation for organizing geological survey programs and assessing mineral and investment opportunities. For decades, scientists have been investigating and proposing various methods for estimating mineral resources in geologic mapping and surveying procedures. Mineral resource assessments are often based on the findings of geological mapping and mineral prospecting on a scale of 1:200,000 to 1:50,000. Many geological and statistical approaches for estimating mineral resources have been developed recently. Among them, the similarity-analogy in ore geology and mineral resource estimation based on statistical methods have been widely used to investigate mineral resources (Byryukov, 1962; Zhang and Huang, 2010; Awadh and Abdulla, 2017; Al-Malabeh et al., 2017; Revuelta, 2018; Hung et al., 2020; Awad and Awadh, 2020). Different estimation methods have been used for different scenarios depending upon the ore boundaries, geological geometry, grade variability, the amount of time, and money availability. To select the suitable methods for the research object, the stage of geological investigation, the completeness of the document, the geological structure characteristics of the object, and mineral type should be investigated carefully. Northeastern Vietnam is evaluated as a location with high kaolinite-pyrophyllite resources (Tri and Khuc, 2011). However, the mineral resource estimation methods have been used based on qualitative description and calculation, which used rigid formulas and parameters, suggesting not suitable for the variability of the mineral market. Moreover, due to the formation characteristics and complex mineral components in ore bodies, this leads to the difficulty in mapping out particular kaolin bodies, and in many cases. Therefore, mineral resources of the kaolin and pyrophyllite ores are being added together during the explored and exploited process. In reality, the calculation and estimation of kaolin resources/reserves in the kaolinite-pyrophyllite orebody not only make sense in scientific terms but also to be the basis for exploitation orientation and processing to ensure the rational use of mineral resources. In order to have a more comprehensive and flexible view of mineral resource estimation, a model for evaluating kaolinite-pyrophyllite resources based on many different boundary content options should be studied in this area. Therefore, northeast Vietnam is an ideal area to apply this asymptotic approach for estimating kaolinite-pyrophyllite resources.

It is proposed that the statistical and similarity-analogy in ore geology methods are suitable for describing the relationship between kaolin resources and aluminum oxide contents at a regional scale, and the distribution of element concentrations in a particular kaolin deposit. Based on the statistical and similarity-analogy in ore geology methods, this paper aims to work out the formulae of the relationships between kaolin tonnage and aluminum oxide contents for mapping out particular kaolin bodies. The Quang Ninh area, northeastern Vietnam, is selected as a case study.

\section{Geological Settings}

\subsection{Geology}

The studied area is located in Quang Ninh Province, Northeastern Vietnam (Fig. 1A). The area has mainly consisted of lower Paleozoic sedimentary rocks (i.e., metamorphic schists, carbonate rocks, and marly sandstone), upper Paleozoic rocks such as limestone, sandstone, coal claystone, volcanosedimentary rocks, and Triassic granitoid rocks (Tuyen, 1995; Luong, 1999). In the center of the Quang Ninh area, conglomerate, gritstone, cross-bedded polymictic sandstone, violet-red brownish siltstone, 
shale (Jurassic-Cretaceous), are extended in the Southwest-Northeast trend. Quaternary sediment distributes along the sea beach and valley. Structurally, the studied area is the northeast part of the Quang Ninh zone, extending from Southwest to Northeast. The Quang Ninh zone is controlled by the Yen TuBinh Lieu and the Trung Luong-Tan Mai strike-slip faults (Dovijkov et al., 1965) (Fig. 1B). These two faults, as well as the other faults running parallel to them, play an important role in regulating the activities of magmatic intrusive rocks and minerals in this area (Tuyen, 1995; Luong, 1999). In addition, other fault systems have formed, further complicating the regional structure.

\subsection{Characteristics of the Kaolinite-Pyrophyllite Orebodies Distribution}

Hydrothermal and metasomatic kaolinite-pyrophyllite ore occurrences are recorded in the Quang Ninh area, of which the Ba Che, Hai Ha, Dam Ha, Binh Lieu, and Mong Cai are the most significant ones (Table 1). These ore occurrences are mainly distributed in the acidic effusive formations of Binh Lieu Formation and belong to the East of An Chau rifting structure that forms mineralized zones longlasting to the Northeast-Southwest and comprises Tan Mai - Chuc Bai Son zone in the Northeast; Hoanh Mo - Binh Lieu zone in the Northwest and Tam Lang - Ba Che zone in the Southwest (Fig. 1B).

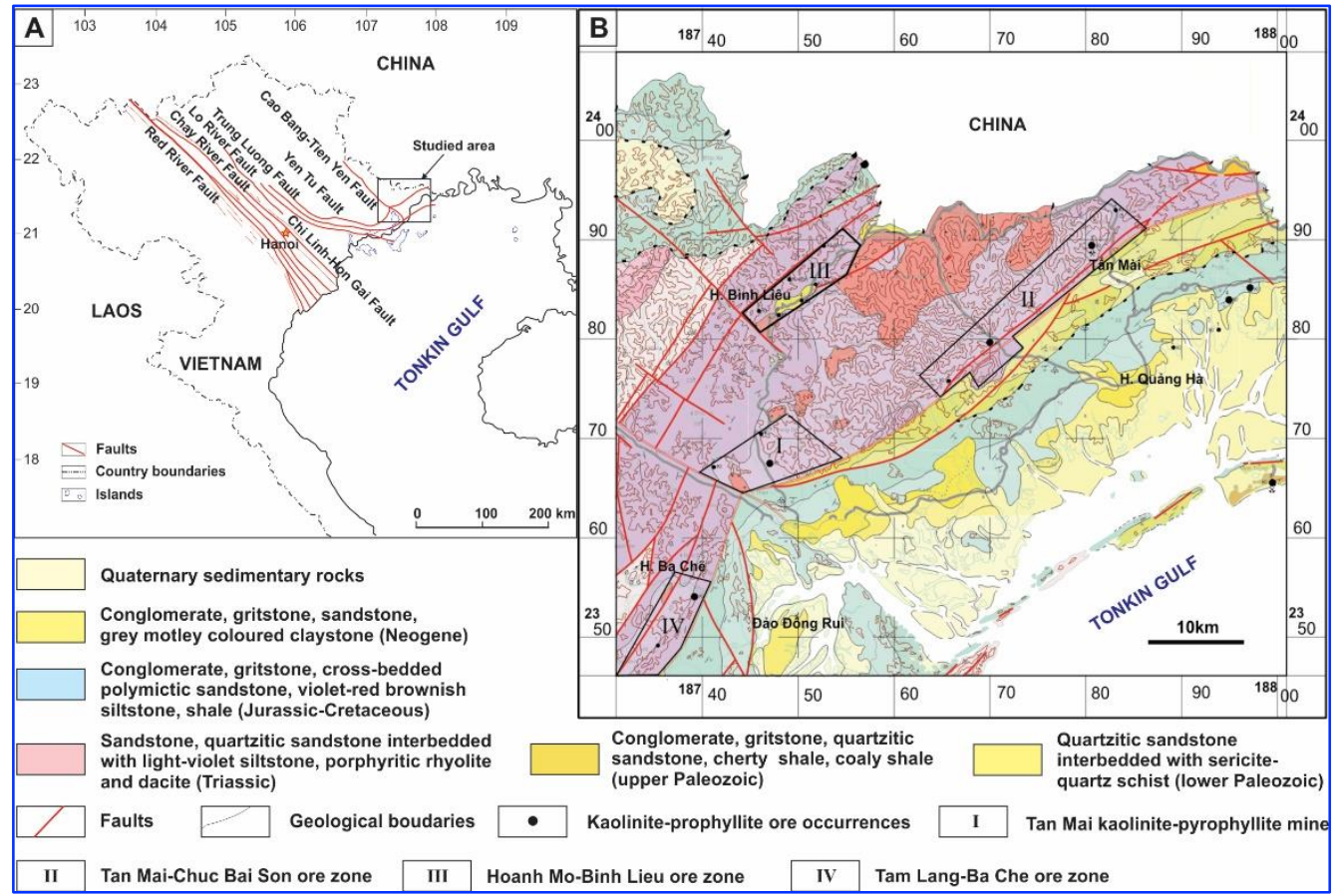

Fig.1. (A) Sketch-map showing the location of the studied area in northeastern Vietnam; (B) Simplified geological map of the Quang Ninh area, showing the location of the kaolinite-pyrophyllite ore occurrences and ore zones (modified from Tuyen, 1995; Luong, 1999).

The kaolinite-pyrophyllite orebodies intrude or coincide with the Northeast-Southwest faulting system and have a complex shape rather, bulges in and out without regularity, and gently dipping angles from $60^{\circ}$ to $70^{\circ}$. In large-scale orebodies, horizontal and vertical zonations have been confirmed (Fig. 2). Vertically, the kaolinite-pyrophyllite mines were divided into three major zones. The lowest zone is called as the alunite one, comprising alunite (75\%), kaolinite (10-25\%), quartz (10-20\%), and other minerals. The second zone, also known as the kaolinite-pyrophyllite one, consists of the kaolinite and pyrophyllite (50 - 60\%), quartz (10 - 20\%). The last one of the high aluminum secondary quartzite includes quartz (50-60\%), sericite and pyrophyllite $(10-30 \%)$, in which chemical contents of the clear/pure pyrophyllite (\%) are $\mathrm{Al}_{2} \mathrm{O}_{3}$ ranging from 25.07 to 28.58 , and $\mathrm{SiO}_{2}$ ranging from 62.34 to 67.96 while those of the clear/pure kaolinite (\%) are $\mathrm{Al}_{2} \mathrm{O}_{3}$ ranging from 34.42 to 39.09 and $\mathrm{SiO}_{2}$ ranging from 43.88 to 45.22 . Therefore, the distinguish between the kaolin and pyrophyllite orebodies can be based 
on the aluminum oxide content $\left(\mathrm{Al}_{2} \mathrm{O}_{3}>28 \%\right)$ (Toan, 1984; Ha, 1991; Hung, 2011). Besides, the main minerals in the kaolin grade I type are kaolinite (20-30\%), pyrophyllite (40-60\%), while those in the kaolin grade II type are kaolinite $(<10 \%)$, pyrophyllite $(20-40 \%)$, and other minerals such as dickite, alunite, sericite (10-40\%), quartz (10-66\%), diaspora, and montmorillonite (5-13\%), etc. Under the Microscope and Scanning electron microscope (SEM) coupled with energy-dispersive X-ray spectroscopy (EDS), it is shown that the kaolinite minerals of the Pec Sec Leng mine are existed as the dickite mineral in the layer forms, overlapping each other (Fig. 3).

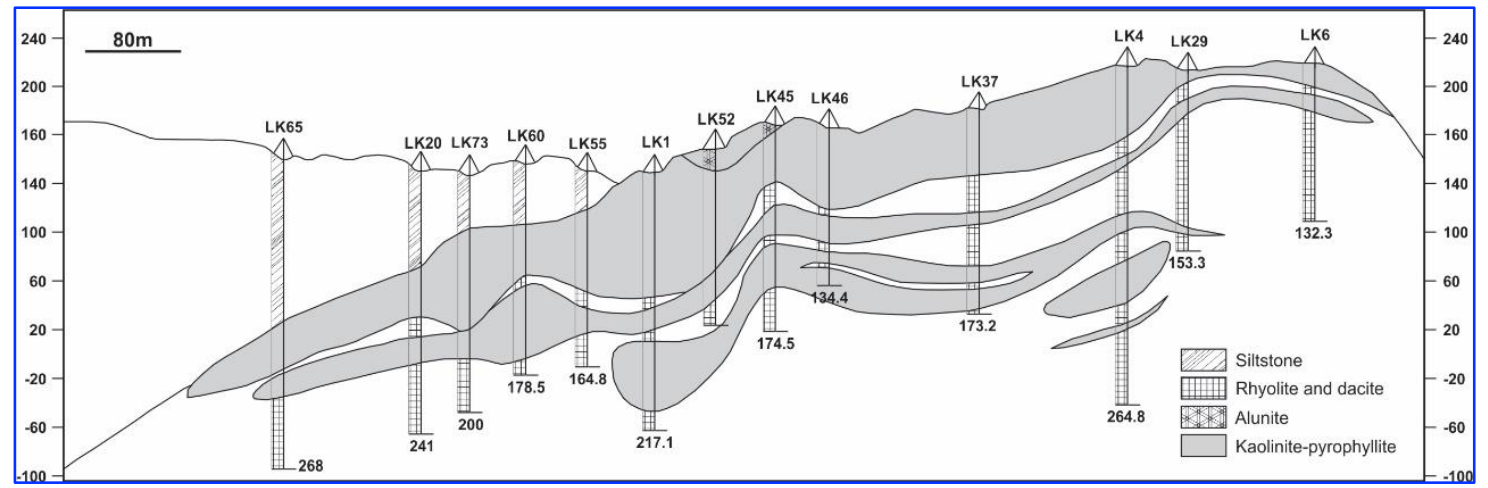

Fig.2. Geological cross-section showing the kaolinite-pyrophyllite orebodies in the Cua Da mine, Quang Ninh Province (modified from Binh, 1985)

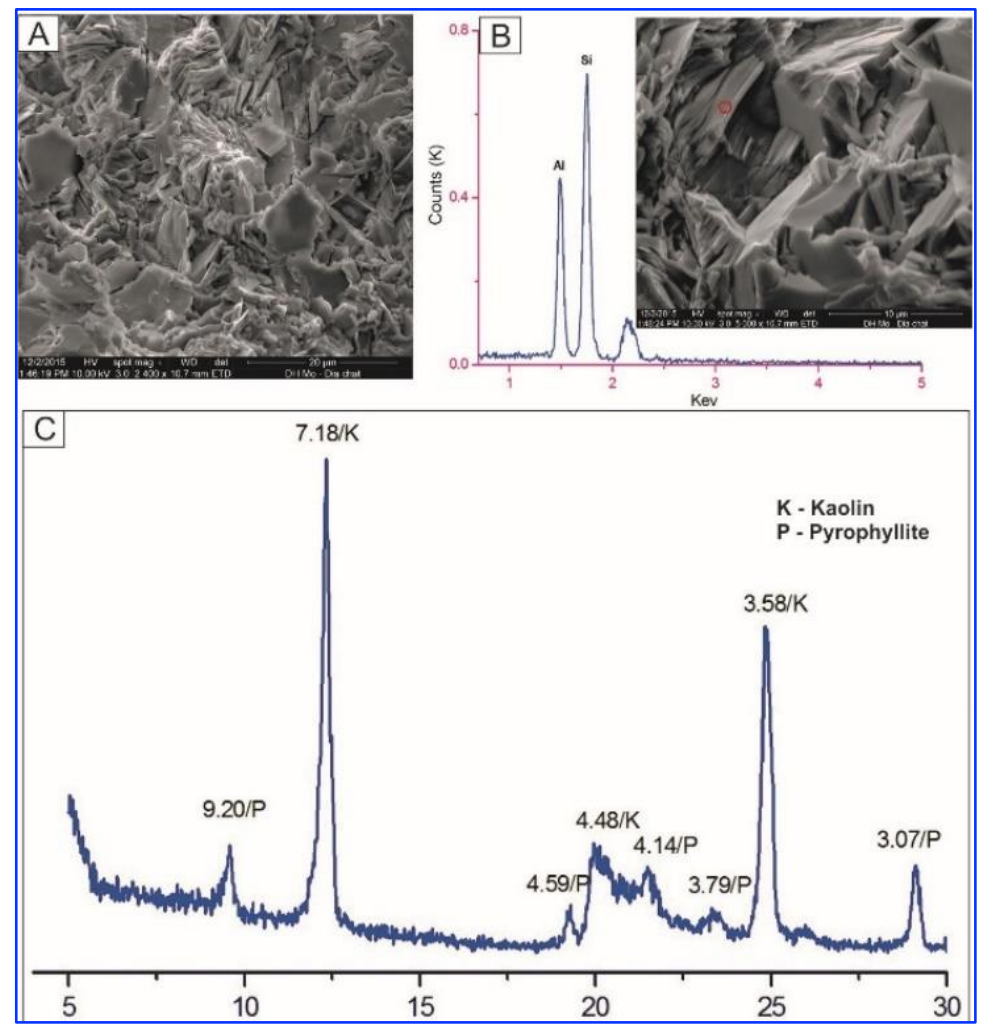

Fig.3. (A, B) SEM photomicrographs and EDS dickite mineral from the Pec Sec Leng kaolinitepyrophyllite mine; (C) Powder X-ray diffraction pattern of untreated kaolin, and the assignment to its component minerals in the Pec Sec Leng mine, Quang Ninh Province (Center for Excellence in Analysis and Experiment, 2015)

In the Quang Ninh area, the huge kaolinite-pyrophyllite orebodies are centralized in the Tan Mai region, including the Tan Mai kaolin mine, which has four major orebodies, namely I (Pec Sec Leng), II (Cua Da), III (Lam Son), and IV orebodies. These orebodies have resulted in 55.5 million tons of 
kaolinite-pyrophyllite at the levels of 122 and 333 (Toan, 1984; Binh, 1985), in which the Pec Sec Leng mine has the highest number of kaolinite-pyrophyllite with 8.314 million tons, it is selected as the standard area for kaolin resource estimation following aluminum oxide contents.

Table 1. The names and locations of the hydrothermal and metasomatic kaolinite-pyrophyllite ore occurrences in the Quang Ninh area (after Tuyen, 1995)

\begin{tabular}{ccc}
\hline Numbers & $\begin{array}{c}\text { Kaolinite-pyrophyllite } \\
\text { ore occurrences/mines }\end{array}$ & $\begin{array}{c}\text { Administrative location } \\
\text { (Village, District) }\end{array}$ \\
\hline 1 & Ping Ho & Ping Ho, Quang Ha \\
2 & Ban Ngai & Ban Ngai, Binh Lieu \\
3 & Khe Lam & Don Dac, Ba Che \\
4 & Che Pha & Dong Tam, Binh Lieu \\
5 & Moc Pai Tien & Quang Son, Hai Ha \\
6 & Khe Khoai & Quang Lam, Dam Ha \\
7 & Tam Lang & Quang Ninh \\
8 & Ngan Trung & Dong Tam, Quang Ha \\
9 & Li Phong & Tien Yen district \\
10 & Dong Muoi & Ba Che district \\
11 & Lang Cong & Ba Che district \\
12 & Khe Dau & Hai Ha district \\
13 & Quang Son & Quang Lam, Dam Ha \\
14 & Deo May & Tan Mai, Ha Coi \\
15 & Tan Mai & Quang Duc, Ha Quang \\
16 & Pec Sec Leng & Na Lang, Binh Lieu \\
17 & Na Lang & Suoi Lenh, Bac Yen \\
\hline 18 & Suoi Lenh &
\end{tabular}

\section{Materials and Methodology}

This study was carried out based on geological surveying and mapping of the geological and mineral resources map of Vietnam at 1:50,000 scale of the Binh Lieu-Mong Cai map sheet group (Tuyen, 1995). There were 810 chemical samples in the Quang Ninh area collected by the Dong Bac Geological Division for analyzing chemical, mineral, and petrography. Surface and drilling efforts, such as openings and core samples, have been used to study the mineralization zones. The mineralized zone of category 334 resources in the Quang Ninh area was studied, using geological features and level research in the studied area, similarity-analogy in ore geology, and mineral resource estimation with statistical techniques. Mineralogically and petrographically, the samples collected from the source rocks were examined. Chemical (major oxides and trace elements) and XRD studies were also performed on two of them. Optical microscopy was used to assess the mineralogy of these materials. X-ray diffraction (XRD-Empyrean) was used to evaluate the mineralogy of clay samples. CuK-radiation was used for the XRD investigations, with a scanning speed of $1^{\circ} 2 \varnothing / \mathrm{min}$. For mineralogical identification, random powder samples were produced. Some orientated $2 \mathrm{~m}$ clay fraction samples on glass slides were airdried, solvated with ethylene glycol at $60^{\circ} \mathrm{C}$ for two hours, and heated at $350{ }^{\circ} \mathrm{C}$ and $550{ }^{\circ} \mathrm{C}$ for two hours.

$\mathrm{X}$-ray fluorescence (XRF) spectrometry (S2 Ranger $\mathrm{x}$-ray spectrometer) was used to analyze major oxides $\left(\mathrm{SiO}_{2}, \mathrm{Al}_{2} \mathrm{O}_{3}, \mathrm{Fe}_{2} \mathrm{O}_{3}, \mathrm{MgO}, \mathrm{CaO}, \mathrm{K}_{2} \mathrm{O}, \mathrm{Na}_{2} \mathrm{O}, \mathrm{P}_{2} \mathrm{O}_{5}, \mathrm{TiO}_{2}\right.$, and $\left.\mathrm{MnO}\right)$ in clays and parent rock samples using Japanese silicate rock reference samples. For each clay sample, the loss on ignition (LOI) was calculated by first drying the samples overnight at $100^{\circ} \mathrm{C}$, then measuring their water and other volatiles contents, such as $\mathrm{CO}_{2}$ and $\mathrm{SO}_{3}$, at $950{ }^{\circ} \mathrm{C}$. Some typical clay samples were prepared for SEM-EDX (SEM Quanta 450) examination by fracturing clay samples with a tool to produce a fresh surface for microstructure study. A thin coating of evaporated gold was then applied to the sample's new surface. All experimental studies were done at the Center for Excellence in Analysis and Experiment HUMG of Vietnam. 


\subsection{Ore Resource Estimation Based on Statistical Method}

The percentage ratio between the kaolin resources and the kaolinite-pyrophyllite one in the studied area is determined based on the standard normal distribution method so as to evaluate the statistical characteristics of the kaolin chemical components and classify the quality of the kaolin ore according to the aluminum oxide content (Tri et al., 2014). Statistics are one of the widely mathematical methods to solve tasks in geological investigation exploration and exploitation in particular. To evaluate the distribution characteristics of the ore body parameters and estimation of the mineral resources and reserves in accordance with statistical models, first of all, the statistical distribution model of the research parameters must be determined. For the standard normal distribution, the equation exactly defines the normal distribution $\varphi(\mathrm{x})$ and normal distribution function $\mathrm{F}(\mathrm{x})$ (Davis, 2002).

$$
\begin{gathered}
\varphi(x)=\frac{1}{\sigma \sqrt{2 \pi}} e^{-\frac{\left(x_{i}-\bar{X}\right)^{2}}{2 \sigma^{2}}}, \\
F(x)=\frac{1}{\sigma \sqrt{2 \pi}} \int_{-\infty}^{x} e^{-\frac{\left(x_{i}-\bar{X}\right)^{2}}{2 \sigma^{2}}} d x
\end{gathered}
$$

in which, $\mathrm{X}$ and $\sigma$ are the mean value and root-mean-square deviation of the random quantity (two parameters of the standard normal distribution rule).

In practical geology, to simplify the estimation, the standard normal distribution function is used by introducing a new variable.

$$
u=\frac{x_{i}-\bar{X}}{\sigma},
$$

In the above formula (3), $\mathrm{x}=\mathrm{u} \sigma+\bar{x}$ and $\mathrm{dx}=\sigma \mathrm{du}$. When changing variable $\mathrm{x}$ with $\mathrm{u}, \mathrm{F}(\mathrm{x})$ integral is upgraded to a new function $\Phi(\mathrm{u})$ as followed.

$$
\Phi(u)=\frac{1}{\sigma \sqrt{2 \pi}} \int_{-\infty}^{u} e^{-\frac{(u \sigma+\bar{X}-\bar{X})^{2}}{2 \sigma^{2}}} \sigma \cdot d u=\frac{1}{\sqrt{2 \pi}} \int_{-\infty}^{u} e^{-\frac{u^{2}}{2}} d u,
$$

Based on the results of defining function $\Phi(u)$, the probabilities of layer $x_{i}=x_{i+1}$ is defined by the following formula.

$$
\mathrm{P}\left(\mathrm{x}_{\mathrm{i}}<\mathrm{x}<\mathrm{x}_{\mathrm{i}+1}\right)=\Phi\left(\mathrm{u}_{\mathrm{i}+1}\right)-\Phi\left(\mathrm{u}_{\mathrm{i}}\right)
$$

The equation for resource and reserve estimation based on cutoff changes (orebody thickness and contents) is expressed as a function following the characteristics of the standard normal distribution. Scientists have proven that there is an inter-dependent relationship demonstrated by the following equation. For ore resource estimation.

For ore resource estimation.

$$
\mathrm{Q}\left(\mathrm{x}_{\mathrm{i}}>\mathrm{x}\right)=\mathrm{Q}_{\mathrm{o}}[1-\Phi(u)]
$$

$$
\mathrm{P}\left(\mathrm{x}_{\mathrm{i}}>\mathrm{x}\right)=\mathrm{C}_{\mathrm{i}}\left[\mathrm{Q}\left(\mathrm{x}_{\mathrm{i}}>\mathrm{x}\right)\right]
$$

where $\mathrm{Q}\left(\mathrm{x}_{\mathrm{i}}>\mathrm{x}\right)$ is the inferred mineral resources/reserves based on the grade of the thickness (or content) within the values $\mathrm{x}_{\mathrm{i}}>\mathrm{x}$ (ton); $\mathrm{P}\left(\mathrm{x}_{\mathrm{i}}>\mathrm{x}\right)$ is the inferred mineral resources/reserves based on the grade content of useful components within the values $\mathrm{x}_{\mathrm{i}}>\mathrm{x}$ (ton); $\mathrm{Q}_{0}$ are the mineral resources estimated by using the traditional method within the ore-bodies contacts that are outlined using the value of $\mathrm{x}_{0}$ (ton); $\mathrm{C}_{\mathrm{i}}$ is the mean thickness (or average content of useful components) for sample sets within the values $\mathrm{x}_{\mathrm{i}}>\mathrm{x}_{1}(\mathrm{~m}, \%)$ as following the formula. 


$$
C_{i}=\frac{\int_{x_{1}}^{x_{m}} x f_{(x)} d x}{\int_{x_{1}}^{x_{m}} f_{(x)} d x},
$$

\subsection{Similarity Analogy in Ore Geology}

Similar-analogy in ore geology was developed based on similar geological environments in different areas named similar mineralization characterization (Byryukov, 1962). This method is created by using a similar model for other ore deposits named similar geological characterization. According to the method, resource estimations are calculated as the formula (Byryukov, 1962).

$$
\mathrm{Q}=\text { S.q.K, }
$$

where Q-resource estimation (ton), K-a similar factor among estimated areas regarding the standard area, q-ore resources in an area unit $\left(\operatorname{ton} / \mathrm{km}^{2}\right)$. The similarity factor $\left(\mathrm{K}_{\mathrm{ij}}\right)$ between areas is determined by the comparative method of ore-forming criteria, which is evaluated by using the information on mining geological characteristics of surrounding rocks as well as the composition of each area. The information is digitized and calculated following the formula.

$$
K=\frac{\sum_{p=1}^{m} a_{i p} b_{j p}}{\sqrt{\sum_{p=1}^{m} a_{i p}^{2} \sum_{p=1}^{m} b_{j p}^{2}}}
$$

where $i, j$-comparative objects, $a_{i p}, a_{j p}$-value of $i$ or $j$ object at $p$ factor $(p=\overline{1, m})$.

\section{Results and Discussion}

\subsection{Kaolin Resource Estimation Based on Statistical Methods}

Based on 810 kaolin chemical samples, the results of the statistical analysis of the aluminum oxide

\begin{tabular}{|c|c|c|c|c|c|c|c|}
\hline \multirow[t]{2}{*}{ Parameter } & \multicolumn{3}{|c|}{ Content (\%) } & \multirow[t]{2}{*}{ Skewness } & \multirow[t]{2}{*}{ Kurtosis } & \multirow{2}{*}{$\begin{array}{l}\text { Variance } \\
(\%)\end{array}$} & \multirow{2}{*}{$\begin{array}{l}\text { Coefficient of } \\
\text { variation }(\%)\end{array}$} \\
\hline & Min & $\operatorname{Max}$ & Mean & & & & \\
\hline $\mathrm{Al}_{2} \mathrm{O}_{3}$ & 6.67 & 40.93 & 25.39 & 1.16 & 1.32 & 34.37 & 29.55 \\
\hline
\end{tabular}
content of the Pec Sec Leng orebody are presented in Table 2.

Table 2. Statistical features of the aluminum oxide content of the Pec Sec Leng orebody

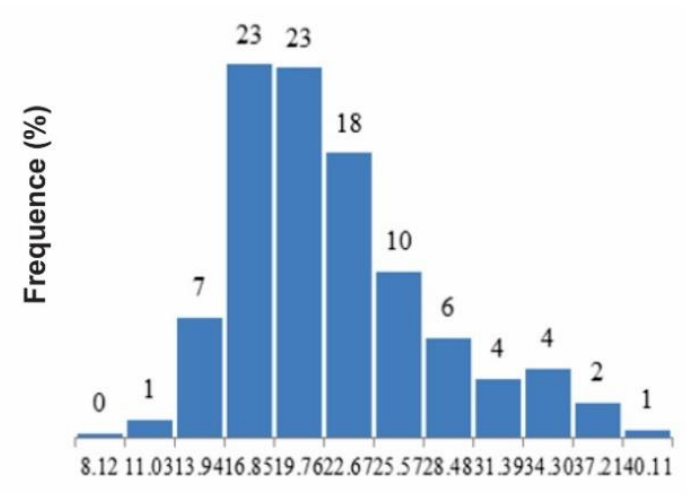

Average layers

Fig.4. The distribution function diagram of the aluminum oxide content of the Pec Sec Leng orebody 
The aluminum oxide content of the Pec Sec Leng orebody shows an average content of $25.39 \%$. Its coefficient of variation (V) of $29.55 \%$ and highly stable distribution indicate that the aluminum oxide content has complied with the standard normal distribution (Fig. 4). Kaolin resource/reserve estimation based on the grade of the aluminum oxide contents is presented in Table 3. Results show that kaolin resources count for the $\mathrm{Al}_{2} \mathrm{O}_{3}$ content over $28 \%$, making up to $14.3 \%$ in the total resources of kaolinitepyrophyllite of Pec Sec Leng mine.

Table 3. Kaolin resource estimation based on the grade of the aluminum oxide contents $\left(\mathrm{x}_{\mathrm{i}}\right)$.

\begin{tabular}{ccclccc}
\hline $\mathbf{x}_{\mathbf{i}}$ & $\mathbf{u}$ & $\mathbf{f}(\mathbf{u})$ & $\mathbf{Q}_{\mathbf{0}}$ (ton) & $\mathbf{Q}_{\mathbf{x}<\mathbf{x i}}$ & $\mathbf{Q}$ resources (ton) & $\mathbf{Q}_{\mathbf{Q}} \mathbf{Q}_{\mathbf{0}}(\boldsymbol{\%})$ \\
\hline 12 & -1.69 & 0.046 & $8,314,000$ & 382,444 & 382,444 & 4.6 \\
19 & -0.46 & 0.323 & & $2,685,422$ & $2,302,978$ & 27.7 \\
21 & -0.10 & 0.46 & & $3,824,440$ & $1,139,018$ & 13.7 \\
25 & 0.60 & 0.726 & & $6,035,964$ & $2,211,524$ & 26.6 \\
28 & 1.12 & 0.869 & & $7,224,866$ & $1,188,902$ & 14.3 \\
34 & 2.18 & 0.985 & & $8,189,290$ & 964,424 & 11.6 \\
39 & 3.06 & 0.999 & & $8,305,686$ & 116,396 & 1.4 \\
\hline
\end{tabular}

Kaolin resource/reserve estimation based on the grade of the aluminum oxide contents is presented in Table 3. Results show that kaolin resources count for the $\mathrm{Al}_{2} \mathrm{O}_{3}$ content over 28\%, making up to $14.3 \%$ in the total resources of kaolinite-pyrophyllite of Pec Sec Leng mine.

\subsection{Kaolin Resource Estimation Based on similarity-Analogy in Ore Geology}

Based on geological information, the studied area is mapped out in three prospective regions of the hydrothermal and metasomatic kaolinite-pyrophyllite deposits, showing a total area of $210 \mathrm{~km}^{2}$. The information combination used to evaluate the zones of the Quang Ninh area includes 24 indicator elements (Table. 4). Very common-3, common-2, less common-1, and absent-0 values are the four groups in which the data are categorized and standardized according to the quantitative principles. In the examined location, a comparable coefficient was produced based on the standardized outcomes of study information (Tab. 5). The $\mathrm{K}_{\mathrm{ij}}$ similar coefficient between subdivisions is quite high, indicating that indicator components, mineral composition, geological representation, and variation of adjacent rocks are all characterized similarly. These findings imply that the geological conditions and variables affecting mineralization in the I, II, III, and IV ore zones are comparable. As a result, utilizing the similarity - analogy in ore geology technique, kaolinite-pyrophyllite resource estimation may be trusted. Similarity levels among estimated areas are calculated by equation 10 . The results on the similarity levels among studied areas are presented in Table 5.

Table 4. Components of feature matrix

\begin{tabular}{|c|c|c|c|c|c|c|c|c|c|c|c|c|}
\hline Object & \multicolumn{12}{|c|}{ Indicator elements or studied factors } \\
\hline I & 1 & 2 & 2 & 1 & 2 & 2 & 3 & 3 & 3 & 3 & 2 & 3 \\
\hline III & 0.3 & 0.2 & 0.1 & 0.3 & 0.2 & 0.2 & 0.3 & 0.3 & 0.3 & 0.4 & 0 & 0 \\
\hline \multirow[t]{2}{*}{ IV } & 0.3 & 0.2 & 0.1 & 0.3 & 0.1 & 0.2 & 0.2 & 0.1 & 0.1 & 0.3 & 0 & 0 \\
\hline & \multicolumn{12}{|c|}{ Indicator elements or studied factors } \\
\hline Object & $\begin{array}{c}13 \\
\text { Zircone }\end{array}$ & $\begin{array}{c}14 \\
\text { Leucoxene }\end{array}$ & $\begin{array}{c}15 \\
\text { Apatite }\end{array}$ & $\begin{array}{c}16 \\
\text { Diaspore } \\
\end{array}$ & $\begin{array}{c}17 \\
\mathrm{Al}_{2} \mathrm{O}_{3} \\
\end{array}$ & $\begin{array}{c}18 \\
\mathrm{SiO}_{2}\end{array}$ & $\begin{array}{c}19 \\
\mathrm{Fe}_{2} \mathrm{O}_{3}\end{array}$ & $\begin{array}{c}20 \\
\mathrm{TiO}_{2}\end{array}$ & $\begin{array}{c}21 \\
\mathrm{CaO}\end{array}$ & $\begin{array}{c}22 \\
\text { MgO }\end{array}$ & $\begin{array}{c}23 \\
\mathrm{~K}_{2} \mathrm{O} \\
\end{array}$ & $\begin{array}{c}24 \\
\mathrm{Na}_{2} \mathrm{O}\end{array}$ \\
\hline I & 3 & 2 & 2 & 2 & 3 & 3 & 1 & 2 & 3 & 3 & 3 & 3 \\
\hline II & 1 & 1 & 0 & 0 & 1 & 1 & 0.5 & 0 & 0 & 0 & 0 & 0 \\
\hline III & 0 & 0 & 0 & 0 & 1 & 0 & 0.3 & 0 & 0 & 0 & 0 & 0 \\
\hline IV & 0 & 0 & 0 & 0 & 1 & 0 & 0.2 & 0 & 0 & 0 & 0 & 0 \\
\hline
\end{tabular}


Table 5. Similarity levels among estimated areas $\left(\mathrm{K} \cdot 10^{-2}\right)$

\begin{tabular}{lcccc}
\hline K $_{\mathrm{ij}}$ & Tan Mai & $\begin{array}{c}\text { Tan Mai } \\
\text { - Chuc Bai Son }\end{array}$ & $\begin{array}{c}\text { Hoanh Mo- } \\
\text { Binh Lieu }\end{array}$ & Tam Lang- Ba Che \\
\hline Tan Mai & 100 & 78 & 56 & 48 \\
Tan Mai-Chuc Bai Son & 78 & 100 & 56 & 65 \\
Hoanh Mo-Binh Lieu & 56 & 65 & 100 & 96 \\
Tam Lang-Ba Che & 48 & 58 & 96 & 100 \\
\hline
\end{tabular}

Results of kaolinite-pyrophyllite resource estimation based on applying equation (9), the similarity levels, and comparison with the standard area (the Pec Sec Leng orebody) are displayed in Table 6. The total estimation results are 158.16 million tons of kaolinite-pyrophyllite in the Quang Ninh area (Table 6), in which kaolin resource estimation accounts for $14 \%$, equal to 22.0 million tons.

Table 6. Results of kaolinite-pyrophyllite resource estimation based on similarity-analogy in ore geology

\begin{tabular}{lcccc}
\hline Ore zone & $\begin{array}{c}\text { Area } \\
\left(\mathbf{S}, \mathbf{~ k m}^{\mathbf{2}}\right)\end{array}$ & $\begin{array}{c}\text { Similarity } \\
\text { levels }\left(\mathbf{K}_{\mathbf{i j}}\right)\end{array}$ & $\begin{array}{c}\text { Ore resources in } \\
\text { the standard area } \\
\left(\mathbf{q}, \mathbf{1 0}^{\mathbf{3}} \text { tons/km } \mathbf{k m}^{\mathbf{2}}\right.\end{array}$ & $\begin{array}{c}\text { Ore resources } \\
\left(\mathbf{Q}, \mathbf{1 0}^{\mathbf{3}} \text { tons }\right)\end{array}$ \\
\hline Tan Mai-Chuc Bai Son & 900 & 0.78 & 0.12 & 84.24 \\
Hoanh Mo-Binh Lieu & 500 & 0.56 & & 33.6 \\
Tam Lang-Ba Che & 700 & 0.48 & & 40.32 \\
Total & & & & 158.16 \\
\hline
\end{tabular}

\section{Conclusions}

The hydrothermal-metasomatic kaolinite-pyrophyllite ore occurrences in the Quang Ninh area exposed along the SW-NE part of the Quang Ninh zone are evaluated in terms of the similarity-analogy in ore geology and the gradual change of the aluminum oxide contents to evaluate kaolin potential in northeastern Vietnam. Through this study, the conclusions can be drawn as follows. The mineral resource estimation based on statistical method shows 2.21 million tons of kaolin based on the aluminum oxide content over $28 \%$ of the Pec Sec Leng mine, accounting for $14.3 \%$ in total. The similarity-analogy in ore geology indicates 158.16 million tons kaolinite-pyrophyllite ores, in which 22.0 million tons of kaolin, making up to $14 \%$ in total. These methods show that the Quang Ninh area contains mainly pyrophyllite instead of kaolin resources. Our study suggests that the Quang Ninh area can be considered as a potential pyrophyllite resource in northeastern Vietnam. Finally, the one resource estimation based on similarity-analogy in ore geology method displays an overview of the prospect on kaolinitepyrophyllite resources, indicating that this method can serve as a basis for the proposed selection of the prospective areas for effective kaolinite-pyrophyllite exploration in the Quang Ninh area, northeastern Vietnam.

\section{Acknowledgements}

The authors are thankful to the Center for Excellence in Analysis and Experiment, Hanoi University of Mining and Geology for providing laboratory facilities. The authors are very grateful to the Editor in Chief Prof. Dr. Salih M. Awadh, the Secretary of Journal Mr. Samir R. Hijab. and the Technical Editors for their great efforts and valuable comments.

\section{References}

Al-Malabeh, A., Al-Smadi, Z., and Ala'li, J., 2017. Mineralogy, geochemistry and economic potential of zircon and associated minerals in Dubaydib sandstone formation, Jordan. Iraqi Geological Journal, 50 (1), 1-11.

Awad, A.M., and Awadh, S.M., 2020. Reserve estimation of late Miocene Injana claystonebeds for Portland cement and brickindustry, middle of Iraq. Iraqi Geological Journal, 53 (1D), 1-16.

Awadh, S.M. and Abdulla, F.H., 2017. Purification of aqueous solutions from $\mathrm{Pb}$ (II) by natural bentonite: an empirical study on chemical adsorption. Environmental Earth Sciences, 76(11), 1-8. 
Awadh, S.M. and Yousif, A.A.H., 2015. Sorption efficiency of kaolinte in removal Cd from aqueous solutions. Iraqi Journal of Science, 56(2C), 1699-1707.

Binh, T.Q., 1985. Report on results of prospecting investigation of kaolinite-pyrophyllite orebodies II, III in the Tan Mai area, Quang Ninh province. Department of Geology and Minerals of Vietnam, Ha Noi (in Vietnamese).

Byryukov, V.I., 1962. Classification of exploration systems of solid mineral deposits (in Russian). Geologiya Rud nykh Mestorozhdenii 1, Moscow, 99-121.

Davis, J.C., 2002. Statistics and Data Analysis in Geology, 3rd Edition. Published by Wiley, 656 pp.

Dovjikov, A.E., My, B.P., Vasilevskaia, E.D., Jamoida, A.I., Ivanov, G.V., Izokh, E.P., Huu, L.D., Mareitchev, A.I., Chien, N.V., Tri, N.T., Luong, T.D., Quang, P.V., Long, P.D., 1965. Geology of North Vietnam. The Explanatory Note of the Geological Map of North Vietnam at 1:500,000 scale. Geological Department of Vietnam, Ha Noi, 584 pp.

Glacken, I.M., Snowden, D.V., 2001. Mineral Resource Estimation, in Mineral Resource and Ore Reserve Estimation - The AusIMM Guide to Good Practice (Ed: A C Edwards), 189-198 (The Australasian Institute of Mining and Metallurgy: Melbourne).

Ha, T.C., 1991. Report on results of prospecting investigation of kaolinite-pyrophyllite orebody IV in the Tan Mai area, Quang Ninh province. Department of Geology and Minerals of Vietnam, Ha Noi (in Vietnamese).

Hung, K.T., Sang, P.N., Phuong, N., Dung, N.T., Bac, B.H., Phi, N.Q., Sang, B.V., 2020. Polymetallic Nodules Resource Estimation in the Suoi Thau-Sang Than Area, northeastern Vietnam. Inżynieria MineralnaJournal of the Polish Mineral Engineering Society, 1 (2), 1-14.

Hung, N.M., 2011. Report on results of prospecting investigation of kaolinite-pyrophyllite orebody I in the Pec Sec Leng area, Quang Ninh province. Department of Geology and Minerals of Vietnam, Ha Noi (in Vietnamese).

Kužvart, M., Böhmer, M., 1986. Prospecting and exploration of mineral deposits. Volume 21, 2nd Edition, Elsevier, Technology \& Engineering, 508 pp.

Luong, N.C., 1999. Geological and Mineral resources map of Vietnam at 1:200,000 scale of the Mong Cai map sheet group. Department of Geology and Minerals of Vietnam, Ha Noi (in Vietnamese).

Revuelta, M.B., 2018. Mineral Resources From Exploration to Sustainability Assessment. Springer Textbooks in Earth Sciences, Geography, and Environment, Springer International Publishing AG 2018.

Toan, T.X., 1984. The mineral association of secondary quartzite origin in the Tan Mai area. Department of Geology and Minerals of Vietnam, Ha Noi (in Vietnamese).

Tri, L.D., Lam, N.V., Phuong, N., Tinh, P.V., 2014. Experimental application of the normal distribution model for estimation of the kaolin resources based on alluminu oxide grades in the Tuyen Quang province. Mining Industry Journal, 4, 16-28.

Tri, T.V., Khuc, V., 2011. Geology and Earth Resources of Vietnam. General Department of Geology and Minerals of Vietnam. Publishing House for Science and Technology, 645 pp.

Tuyen, T.T., 1995. Geological and Mineral resources map of Vietnam at 1:50,000 scale of the Binh Lieu-Mong Cai map sheet group. Department of Geology and Minerals of Vietnam, Ha Noi (in Vietnamese).

USGS, 2014. Minerals Yearbook; United States Geological Survey: Reston, VA, USA.

Yuan, Y., Shi, G., Yang, M., Wu, Y., Zhang, Z., Huang, A., Zhang, J., 2014. Formation of a hydrothermal kaolinite deposit from rhyolitic tuff in Jiangxi, China. Journal of Earth Science, 25 (3), 495-505.

Zhang, Z., Huang, W., 2010. Evaluation method on geological deposit potential value. International Journal of Business and Management, 5 (6). 210-214. 